\title{
Correction to: The CombinADO study to assess the impact of a combination intervention strategy on viral suppression, antiretroviral therapy adherence, and retention in HIV care among adolescents and young people living with HIV: protocol for a cluster-randomized controlled trial
}

Phepo Mogoba ${ }^{1 *}$, Maia Lesosky ${ }^{1}$, Allison Zerbe², Joana Falcao², Claude Ann Mellins ${ }^{3}$, Christopher Desmond ${ }^{4}$, Carlos Arnaldo ${ }^{5}$, Bill Kapogiannis ${ }^{6}$, Landon Myer ${ }^{1}$ and Elaine J. Abrams ${ }^{2,7}$

Correction to: Trials 22, 956 (2021)

https://doi.org/10.1186/s13063-021-05943-w

Following the publication of the original article [1], we were notified of an error in the statistical analysis section. In line 555, in the sentence that begins with: "Planned subgroup analyses include by age group ( ...)" the age categories (i.e., 10-14, 15-19, and 2024) incorrectly appeared as citations in the published article.

The original article has been corrected.

\section{Author details}

${ }^{1}$ Division of Epidemiology \& Biostatistics, School of Public Health \& Family Medicine, University of Cape Town, Level 5, Falmouth Building, Anzio Road, Cape Town, South Africa. ${ }^{2}$ ICAP at Columbia University, Mailman School of Public Health, New York, USA. ${ }^{3}$ HIV Center for Clinical and Behavioral Studies, Department of Psychiatry, New York State Psychiatric Institute and Columbia University Irving Medical Center, New York, NY, USA. ${ }^{4}$ Centre for Rural Health, University of KwaZulu Natal, Durban, South Africa. ${ }^{5}$ Centro de Estudos Africanos, Universidade Eduardo Mondlane, Maputo, Mozambique. ${ }^{6}$ Eunice
Kennedy Shriver National Institute of Child Health and Human Development, Bethesda, MD, USA. ${ }^{7}$ Department of Pediatrics, Vagelos College of Physicians and Surgeons, Columbia University, New York, USA.

Published online: 17 January 2022

\section{Reference}

1. Mogoba, et al. The CombinADO study to assess the impact of a combination intervention strategy on viral suppression, antiretroviral therapy adherence, and retention in HIV care among adolescents and young people living with HIV: protocol for a cluster-randomized controlled trial. Trials. 2021;22:956. https://doi.org/10.1186/s13063-021-05943-w.

The original article can be found online at https://doi.org/10.1186/s13063021-05943-w.

*Correspondence: Phepo.Mogoba@uct.ac.za

'Division of Epidemiology \& Biostatistics, School of Public Health \& Family Medicine, University of Cape Town, Level 5, Falmouth Building, Anzio Road, Cape Town, South Africa

Full list of author information is available at the end of the article

(c) The Author(s). 2022 Open Access This article is licensed under a Creative Commons Attribution 4.0 International License, which permits use, sharing, adaptation, distribution and reproduction in any medium or format, as long as you give appropriate credit to the original author(s) and the source, provide a link to the Creative Commons licence, and indicate if changes were made. The images or other third party material in this article are included in the article's Creative Commons licence, unless indicated otherwise in a credit line to the material. If material is not included in the article's Creative Commons licence and your intended use is not permitted by statutory regulation or exceeds the permitted use, you will need to obtain permission directly from the copyright holder. To view a copy of this licence, visit http://creativecommons.org/licenses/by/4.0/ The Creative Commons Public Domain Dedication waiver (http://creativecommons.org/publicdomain/zero/1.0/) applies to the data made available in this article, unless otherwise stated in a credit line to the data. 